\title{
Blockade of SDF-I/CXCR4 signalling inhibits pancreatic cancer progression in vitro via inactivation of canonical Wnt pathway
}

\author{
Z Wang', Q Ma*,', Q Liu', H Yu', L Zhao', S Shen' and J Yao' \\ 'Department of Hepatobiliary Surgery, The First Affiliated Hospital of Xi'an Jiaotong University, Xi'an 7I006I, China
}

\begin{abstract}
Extra-pancreatic metastasis is a difficult problem for surgical intervention in pancreatic cancer. CXC chemokine receptor 4 (CXCR4) was considered to have an important role in this process. We hypothesized it may contribute to the pancreatic cancer progression through influencing canonical Wnt pathway. The purpose of this study was to examine the functional role of CXCR4 in the progression of pancreatic cancers and explore the possible mechanism. To this end, the relation between CXCR4 and clinical characteristics was analysed. shRNA against CXCR4 was applied to disrupt the SDF-I/CXCR4 signal transduction pathways in pancreatic cancer cell lines. Our results showed that overall survival in the case of patients positive for CXCR4 expression was significantly lower than that in the case of patients negative for CXCR4 expression. Notably, in vitro studies we observed that the abrogation of CXCR4 could obviously influence the pancreatic cancer cell phenotype including cell proliferation, colony formation, cell invasion and also inhibit the TOPflash activity. In addition, Wnt target genes and mesenchymal markers such as Vimentin and Slug were also inhibited in CXCR4 knockdown cells. Collectively, these data reported here demonstrate CXCR4 could modulate the canonical Wnt pathway and perhaps be a promising therapeutic target for pancreatic cancer progression.
\end{abstract} British Journal of Cancer (2008) 99, I695- 1703. doi:I0.1038/sj.bjc.6604745 www.bjcancer.com

Published online 28 October 2008

(C) 2008 Cancer Research UK

Keywords: CXCR4; Wnt; pancreatic cancer progression; RNAi

Pancreatic ductal adenocarcinoma (PDA) is the fourth leading cause of cancer deaths in Western countries (Jemal et al, 2007). It represents a disease with a poor prognosis, and the survival has been further associated with tumours that locally extended beyond the pancreas and metastasize in the regional lymph nodes (Butturini et al, 2008). The reasons behind the peculiar metastatic tropism are largely unknown. It appears that some understanding of the possible mechanism underlying the progression of pancreatic cancer is required to improve the clinical outcome.

Metastasis progress is a complex mechanism in which many factors can potentially influence tumour dissemination (Murphy, 2001). Recently, the function of chemokines in the process of cancer metastasis has attracted increased attention. Chemokines and their receptors are critical mediators of cell migration during routine immune surveillance, inflammation, and development (Singh et al, 2007; O'Hayre et al, 2008). One of the best studied chemokine receptors is CXCR4, primarily because of its role as a coreceptor for HIV entry as well as its ability to mediate the metastasis of a variety of cancers (Balkwill, 2004a). CXCR4 selectively binds the CXC chemokine stromal cell-derived factor 1 (SDF-1, or CXCL12), which has been found to play an important role in tumorigenesis, proliferation, metastasis, and angiogenesis

\footnotetext{
* Correspondence: Dr Q Ma, Department of Hepatobiliary Surgery, The First Affiliated Hospital of Xi'an Jiaotong University, 277 West Yanta Road, Xi'an 7I006I, China; E-mail: qyma56@mail.xjtu.edu.cn

Received 13 May 2008; revised 12 August 2008; accepted 29 September 2008; published online 28 October 2008
}

in cancers (Burger and Kipps, 2006). The expression of CXCR4, confirmed in more than 23 solid cancers, was upregulated on the surface of tumour cells of epithelial origin (Balkwill, 2004b). Moreover, CXCR4-positive tumour cells could migrate toward distant organs in response to SDF-1 gradient. With the inhibition of CXCR4, the growth and invasion could be impaired in some type of cancer cells (Muller et al, 2001; Ottaiano et al, 2005). Involvement of SDF-1/CXCR4 was reported during prostate cancer, ovarian cancer, colorectal cancer, hepatocellular carcinoma as well as pancreatic cancer (Hart et al, 2005; Jiang et al, 2006; Schimanski et al, 2006; Yoshitake et al, 2008). It was reported that CXCR4 was expressed at higher levels in pancreatic cancer cells and could influence the clinical outcome of PDA patients (Wehler et al, 2006; Billadeau et al, 2006). The microarray results showed that pancreatic juice from pancreatic cancer patients contained increased RNA level of the CXCR4 gene (Rogers et al, 2006). Recent evidence has shown that multiple factors could enhance CXCR4 expression, such as hypoxia-inducible factor 1, vascular endothelial growth factor, activation of nuclear factor kappa B and hepatocyte growth factor (Bachelder et al, 2002; Staller et al, 2003; Helbig et al, 2003; Matteucci et al, 2005). However, the relative mechanism underlying the downstream modulation function of SDF-1/CXCR4 on pancreatic cancer progression is poorly understood.

The Wnt $/ \beta$-catenin canonical Wnt-signalling pathway has been implicated in tumorigenesis at several sites, including the colon, rectum, breast, and liver (Peifer and Polakis, 2000). Its central component, namely, $\beta$-catenin, plays a critical role in this process (Nelson and Nusse, 2004). Firstly, $\beta$-catenin is phosphorylated in 
the inactive phase of Wnt pathway with the absence of Wnt or the presence of Wnt inhibitors. The aberrant secretion of Wnt factors or the presence of APC mutation could lead to abnormal $\beta$-catenin activation which in turn leads to the activation of Wnt signalling and the process of epithelial-mesenchymal transition (EMT) (Brabletz et al, 2001; Reya and Clevers, 2005). A number of downstream target genes of $\mathrm{Wnt} / \beta$-catenin signalling have been reported, which play critical roles in carcinogenesis by affecting cell growth, cell cycling, cell survival and invasion (www.stanford. $\mathrm{edu} / \sim \mathrm{rnusse} /$ wntwindow.html). The mutation of APC or $\beta$-catenin which is commonly found in other gastrointestinal cancer could not be always detected in PDA (Abraham et al, 2002). Aberrant activation of Wnt signalling is a significant feature of human pancreatic adenocarcinoma, as revealed by aberrant $\beta$-catenin expression in a significant fraction (30-65\%) of tumours (Lowy et al, 2003; Al-Aynati et al, 2004; Zeng et al, 2006).

Based on previous research on the central role of CXCR4 and the canonical Wnt pathway, we hypothesized that CXCR4 plays a role in the pancreatic cancer metastasis through the $\mathrm{Wnt} / \beta$-catenin pathway (Wang and Ma, 2007). The aim of this study was to determine the role of CXCR4 in pancreatic cancers and elucidate the underlying mechanism.

\section{MATERIALS AND METHODS}

\section{Cell line and culture conditions}

Human pancreatic cancer cell lines (PC-2, PC-3, Miapaca-2, Bxpc-3, and Panc-1) were stored in the Department of Hepatobiliary Surgery, the First Affiliated Hospital of Xi'an Jiaotong University. The cells were cultured in DMEM (Invitrogen, Carlsbad, CA, USA) supplemented with 10\% FBS (Invitrogen, Carlsbad, CA, USA), penicillin $\left(100 \mathrm{U} \mathrm{ml}^{-1}\right)$ and streptomycin $\left(0.1 \mathrm{mg} \mathrm{ml}^{-1}\right)$.

\section{Immunohistochemistry}

Samples including 48 pancreatic carcinoma and 8 normal pancreas specimen were obtained from the Department of Hepatobiliary Surgery, the First Affiliated Hospital of Xi'an Jiaotong University. Immunohistochemical staining for CXCR4 were performed using the SABC kit (Maxim, Fuzhou, China) according to the manufacturer's instruction. Primary antibody for CXCR4 (1:50) was obtained from eBioscience (San Diego, CA, USA) and incubation overnight at $4{ }^{\circ} \mathrm{C}$. For the evaluation of protein expression, the staining intensity was graded as 0 (negative), 1 (weak), 2 (medium), or 3 (strong). The extent of staining was graded as $0(0 \%), 1(1-10 \%), 2(11-50 \%), 3(51-80 \%)$ and $4(>81 \%)$ according to the percentage of positive staining area relative to the total tumour area. The final immunohistochemical staining score was obtained by multiplying the intensity and the extent of staining (Leo et al, 2006).

\section{CXCR4 shRNA expression vector construct}

The human CXCR4 gene sequence (Genbank accession, no. NM_003467) was analysed for a potential siRNA target with the web-based siRNA target finder and design tool provided by Genscript (Piscataway, NJ, USA) and Ambion (Applied Biosystems, Austin, TX, USA) according to the manufacturer's protocol. The following shRNA insert sequence was synthesized: $5^{\prime}$-gatcc TGAGAAGCATGACGGACAAttcaagagaTTGTCCGTCATGCTTCTCA ttttttggaaa-3' (target position: 301 ) and 5'-gatccAGCGAGGTGGAC ATTCATCttcaagagaGATGAATGTCCACCTCGCTttttttggaaa- $3^{\prime}$ (target position: 1093). As a negative control, a vector was also designed, whose inserted sequence was $5^{\prime}$-gatccTTCTCCGAA CGTGTCACGTttcaagagaACGTGACACGTTCGGAGAAttttttggaaa-3', which does not target any region in human genome. Sense and antisense oligonucleotides were annealed. After digestion with
BamHI and HindIII, the fragments were inserted into the shRNA expression vector pRNAT-U6.1/Neo (GenScript Corp., Piscataway, NJ, USA) and confirmed by plasmid sequencing.

\section{Stable transfection of CXCR4 shRNA expression vector}

In a 24 -well plate, $5 \times 10^{4}$ cells were plated per well 1 day before transfection. Transfection was performed using the lipofectamine 2000 (Invitrogen, Carlsbad, CA, USA) according to the manufacturer's suggestion. At $24 \mathrm{~h}$ after transfection, the cell solution was diluted at $1: 10$ and regenerated. In the 10\% DMEM culture, $400 \mu \mathrm{g} \mathrm{ml}^{-1} \mathrm{G} 418$ (Invitrogen, Carlsbad, CA, USA) was added for selection after the cells adhered to the plate. A limited dilution was used in a 96-well plate for repeated colony selection. After 14 days, $\mathrm{G} 418\left(200 \mu \mathrm{g} \mathrm{ml}^{-1}\right)$ was added for the future stable transfected cell culture.

\section{Quantitative real-time polymerase chain reaction (QT-PCR) to detect mRNA expression}

To extract total RNA, $2 \times 10^{5}$ cells were harvested with the Trizol Reagent (Invitrogen, Carlsbad, CA, USA). cDNA synthesis was conducted as followed with the SYBR ${ }^{\circledR}$ ExScript ${ }^{\text {TM }}$ RT - PCR kit (Takara Biotechnology Co. Ltd., Dalian, China) according to manufacturer's instruction: $500 \mathrm{ng}$ total RNA was mixed with $2 \mu \mathrm{l}$ of $5 \times$ ExScript $^{\mathrm{TM}}$ RTase buffer, $0.5 \mu \mathrm{l}$ of dNTP mixture, $0.5 \mu \mathrm{l}$ of random hexamers, $0.25 \mu \mathrm{l}$ of ExScript ${ }^{\mathrm{TM}}$ Rtase, and $0.25 \mu \mathrm{l}$ of RNase inhibitor in a total volume of $10 \mu$ l. The reactions were performed at $42^{\circ} \mathrm{C}$ for $12 \mathrm{~min}$, followed by inactivation of the reverse transcriptase at $95^{\circ} \mathrm{C}$ for $2 \mathrm{~min}$. The cDNA was stored at $-20^{\circ} \mathrm{C}$. QT-PCR was performed on an ABI PRISM ${ }^{(\mathbb{R}} 7300$ Sequence Detection System (Applied Biosystems, Foster City, CA, USA) with the SYBR Green Master Mix. The final reaction volume was $25 \mu \mathrm{l}$ and contained $12.5 \mu \mathrm{l} 2 \times \mathrm{SYBR}^{\mathbb{B}}$ Premix Ex Taq ${ }^{\mathrm{TM}}, 1.0 \mu \mathrm{l}$ of each primer $(10 \mu \mathrm{M}), 0.5 \mu \mathrm{l} 50 \times$ ROX reference dye, and $1.0 \mu \mathrm{l} \mathrm{cDNA}$. The cycling conditions were as follows: initial denaturation at $95^{\circ} \mathrm{C}$ for $10 \mathrm{~min}$, followed by 40 cycles of $95^{\circ} \mathrm{C}$ for $15 \mathrm{~s}$, and $60^{\circ} \mathrm{C}$ for $60 \mathrm{~s}$. Each measurement was performed in triplicate, and no-template controls were included for each assay. In each QT-PCR, a dissociation curve analysis was conducted. GAPDH was applied as the internal housekeeping gene control. Relative gene expression was calculated using the $2^{-\Delta \Delta C_{t}}$ method (Livak and Schmittgen, 2001).

\section{Cell proliferation assay}

Cells were seeded in a 96-well plate at a concentration of $5 \times 10^{3}$ per well a day before the experiment. 3-[4,5-Dimethylthiazol-2-yl]2,5-diphenyltetrazolium bromide (MTT, $0.5 \mathrm{mg} \mathrm{ml}^{-1}$, SigmaAldrich, St. Louis, MO, USA) was added to each well at 1, 2, 3, 4, 5 days after seeding. Generally, cells were cultured at $37^{\circ} \mathrm{C}$ for $4 \mathrm{~h}$, and then $150 \mu \mathrm{l}$ DMSO was added. The absorption value was measured at a wavelength of $490 \mathrm{~nm}$.

\section{Flow cytometric analysis}

Before flow cytometric analysis, $1 \times 10^{6}$ cells were collected, washed two times with PBS, and fixed with ice-cold $70 \%$ ethanol for $24 \mathrm{~h}$ at $4^{\circ} \mathrm{C}$. The fixed cells were stained with propidium iodide (Beckman Coulter, Miami FL, USA). After incubation for $30 \mathrm{~m}$ at $37^{\circ} \mathrm{C}$, the samples were analysed by a Flow Cytometry. Cell cycle analysis of DNA histograms was performed with the MultiCycle software.

\section{Soft agar colony formation assay}

In six-well plates, each well contained a bottom layer of $1 \%$ agarose, a middle layer of $0.5 \%$ agarose which included $7.5 \times 10^{3}$ 

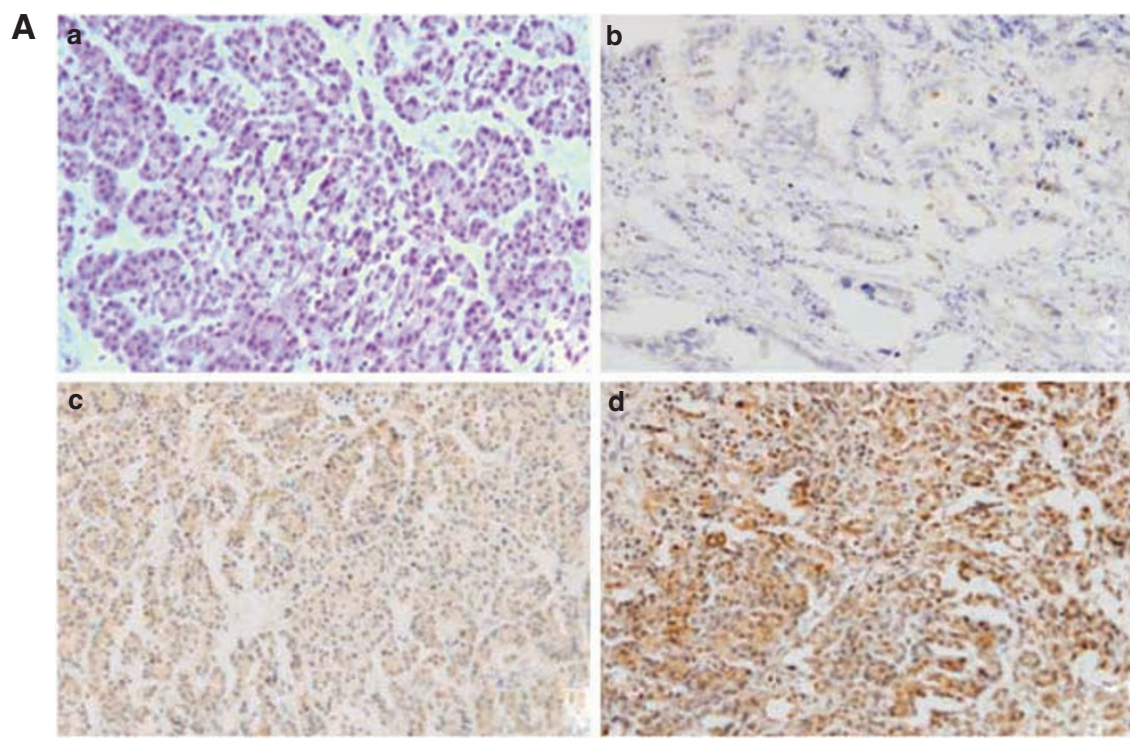

B

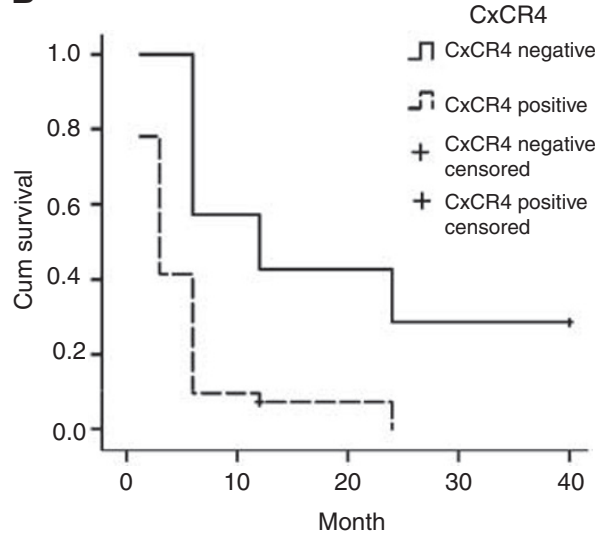

C

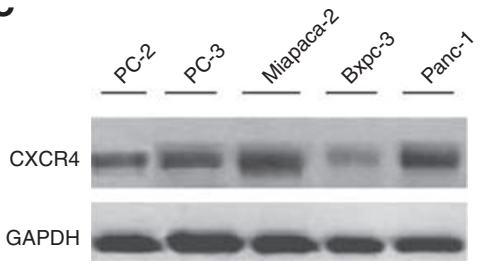

Figure I The expression of CXCR4 on pancreatic cancers. (A) immunohistochemistry staining of CXCR4 on normal pancreatic tissues (a) and pancreatic cancer tissues $(\mathbf{b}-\mathbf{d}) \times 200$ : negative expression $(\mathbf{a})$, weak expression $(\mathbf{b})$, moderate expression $(\mathbf{c})$, strong expression (d); (B) Kaplan - Meier curve showed that the median survival time of the CXCR4-positive and CXCR4-negative groups was 5.5 and I3.5 months; (C). Western blot analysis revealed the CXCR4 expression for 5 pancreatic cancer cells (PC-2, PC-3, Miapaca-2, Bxpc-3, Panc- I). GAPDH was used as a loading control.

Table I The relation between CXCR4 expression and clinical characteristics in PDA patients

\begin{tabular}{lcc}
\hline Clinical pathologic variables & CXCR4 median score & P-value \\
\hline Age & 5.6 & \\
$>65$ & 4.4 & 0.542 \\
$<65$ & & \\
Histology & 3.1 & \\
Well & 4.9 & 0.062 \\
Moderate & 5.5 & \\
Poor & & \\
& & \\
Lymph node metastasis & 6.1 & \\
Positive & 3.0 & \\
Negative & & \\
TNM stage & & \\
I & 1.7 & \\
II & 3.8 & \\
III & 5.4 & \\
IV & 7.9 & \\
\hline
\end{tabular}

cells, and a top layer of medium. The medium at the top layer was changed on every sixth day. After 14 days, cells were stained with Giemsa solution (Gibco-BRL, Gaithersburg, MD, USA) and counted by Quantityone analysis software (BioRad Inc., Hercules, CA, USA).

\section{Protein extraction and western blotting}

Total protein was isolated from $1 \times 10^{7}$ cells with $200 \mu$ l of ice-cold lysis buffer containing $1 \%$ Nonidet P-40 (NP-40), $50 \mathrm{mmoll}^{-1}$ Tris (pH 7.4), $150 \mathrm{mmoll}^{-1} \mathrm{NaCl}, 0.1 \%$ sodium dodecyl sulfate (SDS), $0.5 \%$ deoxycholate, $200 \mu \mathrm{g} \mathrm{ml}^{-1}$ phenylmethanesulfonyl fluoride (PMSF), and $50 \mu \mathrm{g} \mathrm{ml}^{-1}$ aprotinin. Insoluble materials were removed by centrifugation at $15000 \mathrm{~g}$ for $15 \mathrm{~min}$ at $4^{\circ} \mathrm{C}$. The concentration of the extracted protein was measured spectrophotometrically with Coomassie G-250. Clarified protein lysates $(30-80 \mu \mathrm{g})$ were electrophoretically resolved on a denaturing SDSpolyacrylamide gel $(8-12 \%)$, and electrotransferred onto nitrocellulose membranes. The membranes were initially blocked with $5 \%$ nonfat dry milk in Tris-buffered saline (TBS) for $2 \mathrm{~h}$ and then probed with primary antibodies against the specific protein and 

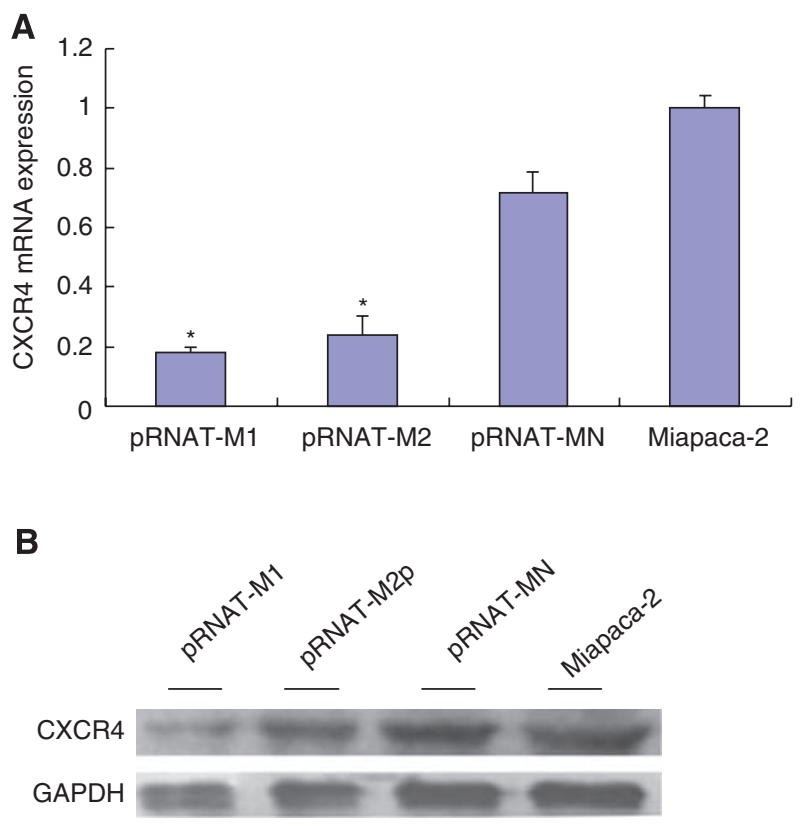

C

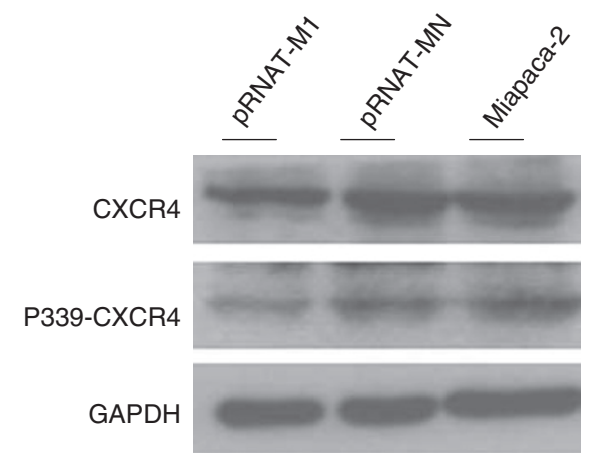

Figure 2 Establishment of stable CXCR4 knockdown. (A) QT-PCR analysis of CXCR4 expression after the transfection of different CXCR4 shRNA expression vectors: pRNAT-MI (target position: 30 I), pRNAT-M2 (target position: 1093), pRNAT-MN (negative control) and Miapaca-2, $* P<0.05$ compared with pRNAT-MN cells; (B) western blot with CXCR4 antibody for different transfected pancreatic cancer cells. GAPDH was detected as a loading control; (C) Western blot showed the different expressions of CXCR4, phosphorylated CXCR4 on Serine 339 (P339CXCR4) on transfected cells. GAPDH was detected as a loading control.

GAPDH (as loading control). After coincubation with the primary antibodies at $4{ }^{\circ} \mathrm{C}$ overnight, the membranes were hybridised with the secondary alkaline phosphatase-conjugated goat anti-rabbit antibody $(1: 2000)$, goat anti-mouse antibodies $(1: 3000)$ (Kangchen, Shanghai, China) for $2 \mathrm{~h}$ at room temperature. The immunopositive bands were examined by an enhanced chemiluminescence (ECL) detection system (Amersham Bioscience, Piscataway, NJ, USA) and the images were transferred onto an $\mathrm{X}$-ray film. The western blot was graded positive if the band of interest was present at the expected molecular weight corresponding to each marker protein. All analyses were done in duplicate. Antibodies used in this study: CXCR4 $(1: 200)$ and MMP-9 $(1: 250)$ (NeoMarkers, Fremont, CA, USA), Vimentin $(1: 200)$ and GAPDH $(1: 400)$ (Santa Cruz Biotechnology, Santa Cruz, CA, USA), P339CXCR4 antibody $(1: 200)$ was kindly provided by Professor Joshua B. Rubin in Washington University School of Medicine at St Louis.

\section{$\beta$-Catenin/Tcf transcription reporter assay}

Briefly, $1 \times 10^{5}$ cells were seeded per well in a 24 -well plate before transient transfection with the construct TOPflash or FOPflash reporter plasmid (Millipore, Billerica, MA, USA). TOPflash comprised three copies of the Tcf/Lef sites upstream of a thymidine kinase (TK) promoter and the Firefly luciferase gene. FOPflash comprised three mutated copies of Tcf/Lef sites and were used as a control for measuring nonspecific activation of the reporter. All transfections were performed using $0.8 \mu \mathrm{g}$ of TOPflash or FOPflash plasmid and $2 \mu \mathrm{l}$ lipofectamine 2000 . To normalise the transfection efficiency in reporter assays, the cells were cotransfected with $0.02 \mu \mathrm{g}$ of an internal control reporter plasmid, containing Renilla reniformis luciferase driven by the TK promoter. At $24 \mathrm{~h}$ after TOPflash or FOPflash transfection, the luciferase assay was performed with the Dual Luciferase Assay System kit (Promega Corp., Madison, WI, USA). Relative luciferase activity was reported as the fold induction after normalization for transfection efficiency.

\section{Matrigel invasion assay}

An invasion assay was performed with a Millicell invasion chamber (Millipore, Billerica, MA, USA). The $8 \mu \mathrm{m}$ pore inserts were coated with $15 \mu \mathrm{g}$ of Matrigel (Becton Dickinson Labware, Bedford, MA, USA). Normal culture medium with or without $100 \mathrm{ng} \mathrm{ml}^{-1}$ SDF-1 $\alpha$ (R\&D systems Inc., Minneapolis, MN, USA) was added at the bottom chamber to induce the cancer cell lines. Cells $\left(5 \times 10^{4}\right)$ were seeded in the top chamber. The Matrigel invasion chamber was incubated for $20 \mathrm{~h}$ in a humidified tissue culture incubator. Noninvading cells were removed from the top of the Matrigel with a cotton-tipped swab. Invading cells on the bottom surface of filter were fixed in methanol and stained with Giemsa. Invasion ability was determined by counting the stained cells.

\section{Statistical analysis}

All statistical analyses were performed using the SPSS13.0 software. The results were presented as means \pm s.d. of three replicate assays. Differences between the groups were assessed by the Student's $t$-test or analysis of variance (ANOVA). $P<0.05$ was considered to indicate statistical significance.

\section{RESULTS}

\section{Association of CXCR4 expression level with pancreatic cancers}

Immunohistochemistry staining results showed that CXCR4 expression was detected not in the normal pancreatic cells but in the cytoplasm of most pancreatic cancer cells. The representative staining results are shown in Figure 1A. Different CXCR4 expression was observed between the non-metastasized and metastasized cells, and observed among the tumour node metastasis (TNM) stages ( $P=0.012,0.005$, respectively) (Table 1$)$. The median survival time of the CXCR4-positive and CXCR4negative groups were 5.5 and 13.5 months, respectively $(P<0.05)$ (Figure 1B). Moreover, CXCR4 expression was highly expressed in pancreatic cancer cell lines, especially Miapaca-2 (Figure 1C).

\section{Establishment of stable CXCR4 knockdown}

Knockdown of transcripts using shRNA is a powerful tool for studying gene function. To study the long-term growth pattern of tumour cells in vitro, we developed pRNAT-U6.1/Neo vectors containing small hairpin constructs capable of generating 19 nucleotide duplex RNAi oligonucleotides. We succeeded in obtaining stable shRNA vector-transfected cells termed 

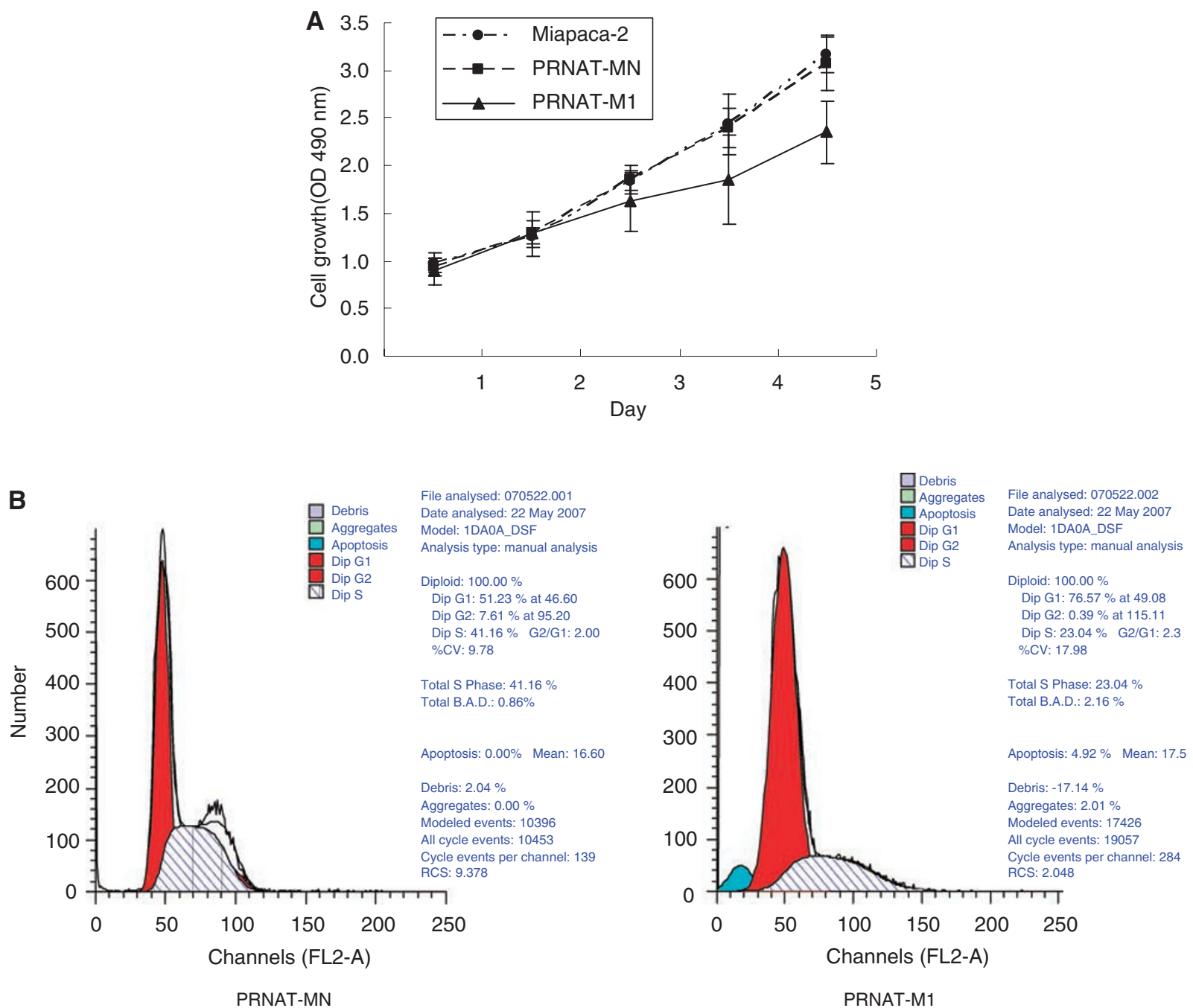

C

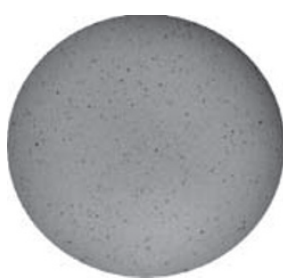

pRNAT-M1

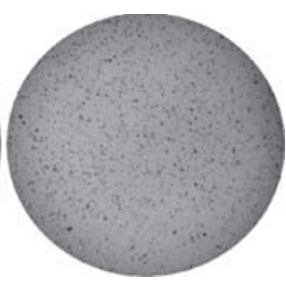

pRNAT-MN

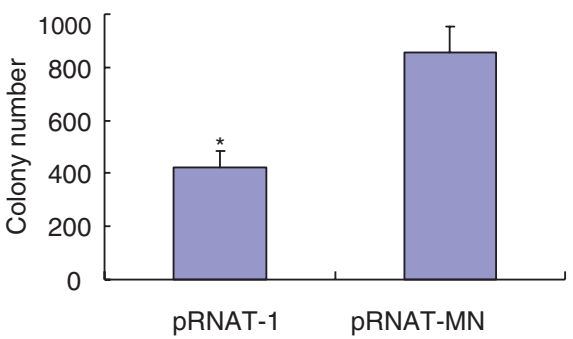

Figure 3 The influence of CXCR4 knockdown on the cell phenotype. (A) MT assay was analysed for pRNAT-MI, pRNAT-MN, and Miapaca-2 on days I, 2, 3, 4, and 5; (B) Distribution of cell cycle phases was demonstrated by flow cytometric analysis for pRNAT-MI and pRNAT-MN; (C) Soft agar assay was assessed to evaluate the cell colony formation ability. The count number of the colony was shown in the diagram; $* P<0.05$ compared with pRNAT-MN cells.

pRNAT-M1 (target position: 301), pRNAT-M2 (target position: 1093), and pRNAT-MN (negative control vector). QT-PCR analysis showed that compared with pRNAT-MN cells, the CXCR4 mRNA expression was inhibited up to $70 \%$ in CXCR4 shRNAtransfected cell lines, particularly in pRNAT-M1 cells $(P<0.05)$. Compared with Miapaca- 2 cells, approximately $20 \%$ decrease of CXCR4 mRNA expression in pRNAT-MN cells was founded (Figure 2A). Moreover, the CXCR4 protein level was also downregulated significantly in pRNAT-M1 cells than in pRNAT-MN cells (Figure 2B). Notably, the decrease of CXCR4 phosphorylation at serine 339 was observed in pRNAT-M1 cells. By band analysis, the proportion of phosphorylated CXCR4 was also reduced in pRNAT-M1 cells (Figure 2C).

\section{Abrogation of CXCR4 inhibits cell proliferation, delays cell cycle and decreases colony-forming ability}

To confirm the effect of CXCR4 inhibition on cell growth, stable transfectants with CXCR4 shRNA were cultured. MTT assay showed that the pRNAT-M1 cells grew slower than pRNAT-MN cells. On the fifty day after seeding, different growth was noticed between pRNAT-M1 and pRNAT-MN cells $(P<0.05)$. However, 
phase (1.61 vs $0.39 \%)$. Moreover, sub-G1 apoptotic compartment was also observed in pRNAT-M1 cells (Figure 3B). To explore the effect of CXCR4 knockdown on tumorigenesis in vitro, we performed soft agar colony formation assay. It showed that the colony formation by pRNAT-M1 cells was decreased than that by pRNAT-MN cells $(P<0.05)$ (Figure $3 \mathrm{C})$.

\section{CXCR4 knockdown inhibits Wnt activity, Wnt target gene and invasion-related genes}

As an important pathway for gastrointestinal cancer development, the $\mathrm{Wnt} / \beta$-catenin pathway and genes associated with cell invasiveness were paid more attention. The $\beta$-catenin/Tcf transcription reporter assay was recognised as an important assessment method for evaluation of the Wnt pathway activity. As TOPflash has three TCF-binding sites, it could be applied to represent the activation of the Wnt pathway. Our data showed that compared with the pRNAT-MN cells, the CXCR4 knockdown cells exhibited a decreased TOPflash activity $(P<0.05)$ and unchanged FOPflash activity (Figure 4A). Moreover, QT-PCR analysis showed that Wnt target genes such as CTNNB1, UPA, and CD44 were inhibited in pRNAT-M1 cells, but the expression of MYC and CCND1 did not change (Figure 4B). At the same time, the inhibition of CXCR4 resulted in decreased Slug, Vimentin and MMP-9 expression $(P<0.05)$ (Figure $4 \mathrm{C})$.

\section{CXCR4 knockdown decreases the invasion of pancreatic cancer cells}

The Matrigel invasion assay was performed to assess the invasiveness of the cancer cells. Representative staining results were shown at Figure 5A. The results showed that pRNAT-MN cells were more invasive than pRNAT-M1 cells $(P<0.05)$. After the SDF-1 stimulation, pRNAT-MN cells showed an obvious increase in invasiveness $(P<0.05)$, but pRNAT-M1 cells demonstrated a slight increase (Figure 5B).

\section{DISCUSSION}

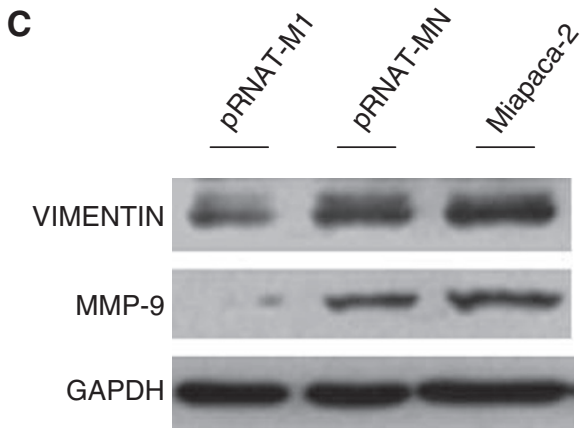

Figure 4 The influence of CXCR4 knockdown on Wnt target gene and invasion-related genes. (A) $\beta$-Catenin/Tcf transcription reporter assay. Normalised with control reporter plasmid, the relative luciferase activity was demonstrated. $* P<0.05$ compared with pRNAT-MN cells; (B) QTPCR analysis to examine the CTNNBI ( $\beta$-catenin), UPA, SLUG, CD44, MYC(c-MYC), Vim (Vimentin), CCNDI (cyclin DI) gene expression by the $2^{-\Delta \Delta C_{\mathrm{t}}}$ method. $* P<0.05$ compared with pRNAT-MN cells; $(\mathbf{C})$ western blot analysis to detect MMP-9 and Vimentin protein expression. GAPDH was used as a loading control.

there was no difference between Miapaca-2 cells and pRNAT-MN cells $(P>0.05)$ (Figure $3 \mathrm{~A})$. According to the analysis of cell cycle distribution by flow cytometry, we found a prolonged and prominent delay in progression from G0 to G1 phase (51.23 vs $76.51 \%)$, a decrease at the $S$ phase (41.16 vs $23.0 \%$ ) and G2-M
The majority of PDA patients have locally advanced or metastatic disease and thus are not candidates for surgical intervention (Winter et al, 2006). The main cause is the extra-pancreatic invasion and metastasis to the liver, lung or other tissues. Many factors such as adhesion molecules, proteases, cytokines, and chemokine are involved in this process. A complex network of chemokine and chemokine receptors exist in tumour microenvironment. The chemokine receptor CXCR4 is one of the representative target genes (Schrader et al, 2002; Brand et al, 2005; Saur et al, 2005; Billadeau et al, 2006). In this study, we demonstrated that overall survival in the case of patients positive for CXCR4 expression was significantly lower than that in the case of patients negative for CXCR4 expression. Elevated CXCR4 expression was correlated to an advanced cancer stage and metastasis. It is similar to previous reports and also suggests that CXCR4 may be a useful marker for cancer progression (Wehler et al, 2006; Kajiyama et al, 2008).

Previous study showed siRNA directed against CXCR4 could inhibit breast cancer migration in vitro (Liang et al, 2005), but the influence of CXCR4 knockdown on pancreatic cancer was hardly known. Considering the important role of CXCR4 in cancer progression, we designed a CXCR4 shRNA vector as an alternative to blocking receptor/ligand interaction. To avoid the empty vector backbone influence, we applied the pRNAT-MN as control cells effectively inhibit the CXCR4 expression. At the same time, the phosphorylation of CXCR4 at serine 339 was obviously reduced, and the proportion of phosphorylated CXCR4 was decreased. instead of Miapaca- 2 cells. Our data showed that the plasmid could 

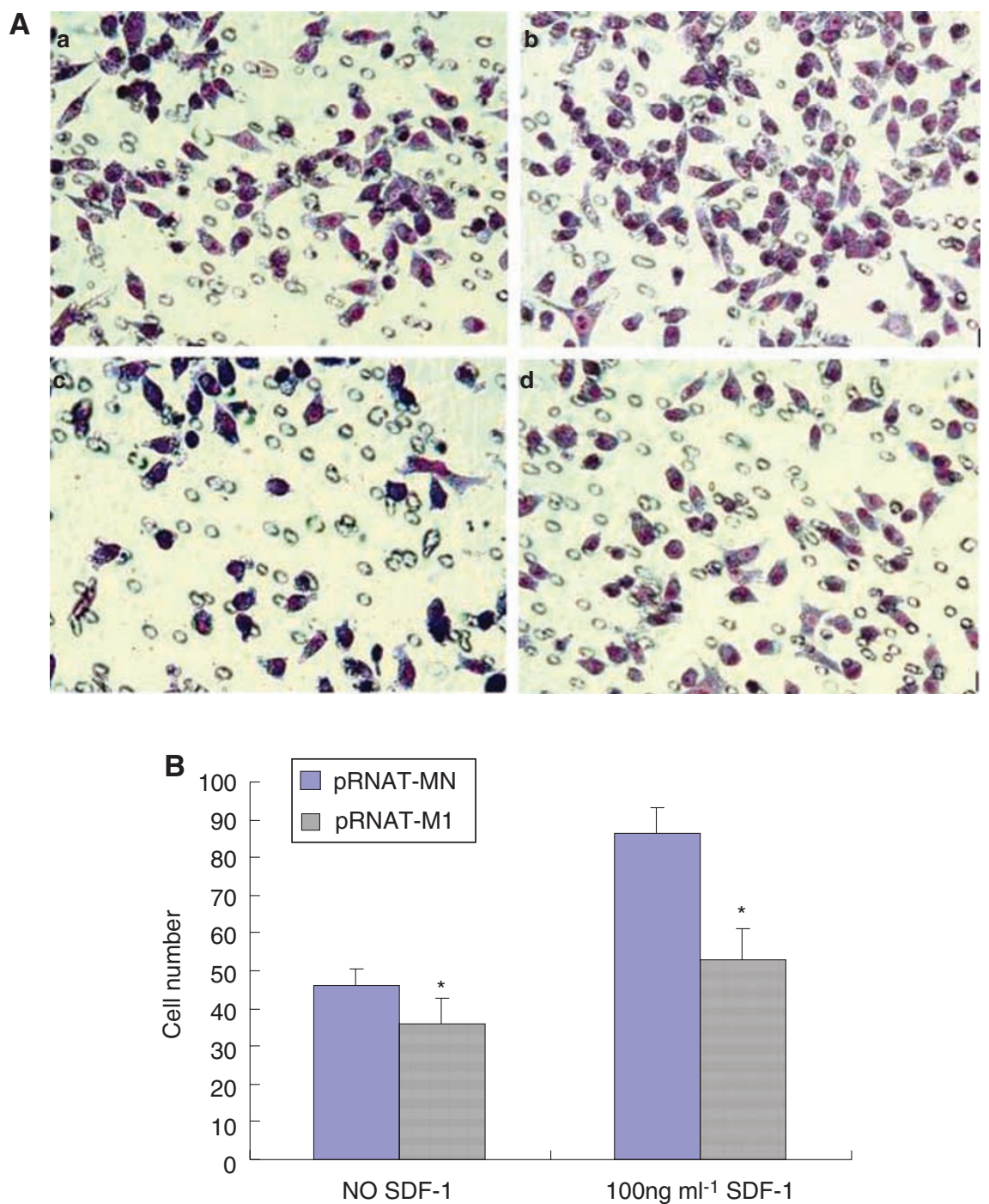

Figure 5 The abrogation of CXCR4 inhibits the invasive potential ability of pancreatic cancer cells. $\times 200$; (A) representative staining figure: pRNAT-MN invading cells without SDF- I stimulation (a), pRNAT-MN invading cells with $100 \mathrm{ng} \mathrm{m}{ }^{-1}$ SDF-I stimulation (b), pRNAT-MI invading cells without SDF- I stimulation (c), pRNAT-MI invading cells with $100 \mathrm{ng} \mathrm{ml}^{-1}$ SDF-I stimulation (d); (B) the diagram of the count analysis, *P<0.05 compared with pRNATMN cells.

Recently, it was shown that the phosphorylation of CXCR4 at serine 339 may be a way to express the CXCR4 function on the cells (Woerner et al, 2005), thus our data further confirmed that CXCR4 shRNA-transfected cells could effectively inhibit CXCR4 function in pancreatic cancers.

Tumorigenesis is the result of cell cycle disorganisation, leading to uncontrolled cellular proliferation and cancer progression. In this study, we demonstrated that the block of CXCR4 could not only decrease pancreatic cancer cell growth, but also increase sub$\mathrm{G} 1$ apoptotic compartment, prolong the G0-G1 cycle and reduce the $\mathrm{G} 2$ and $\mathrm{S}$ phase. At the same time, it may lower anchorageindependent growth ability. With the CXCR4 knockdown, cell growth, cell cycle and cell colony formation ability were inhibited, so pancreatic cancer cell tumorigenesis was prevented effectively.

Deregulation of Wnt signalling is a well-established hallmark of certain human cancers, such as colorectal cancer and melanoma (Ilyas, 2005). Activation of the Wnt target gene will contribute to the development of cancer in terms of proliferation, invasion and metastasis, and angiogenesis (Taketo, 2006; Neth et al, 2007). Additionally, inhibition of Wnt signalling could reduce cell proliferation and increase apoptosis in pancreatic adenocarcinoma cells (Miao et al, 2003; Pasca di Magliano et al, 2007; Nawroth et al, 2007). Here, the $\beta$-catenin/Tcf assay showed that the TOPflash luciferase activity was obviously decreased whereas FOPflash luciferase activity has no change. Moreover, the expression of Wnt target genes including CTNNB1, CD44, UPA, and MMP-9 were markedly decreased. Thus, we assumed that the TCF-binding activity in CXCR4 knockdown cells could be effectively inhibited, which may influence the $\mathrm{Wnt} / \beta$-catenin signalling and the Wnt target gene could not be activated. However, as the canonical Wnt pathway and $\beta$-catenin were regulated by multiple factors together, only blocking CXCR4 expression could not totally inhibit Wnt pathway.

Next, we evaluated the expression of invasion-related genes Vimentin and Slug expression. These two genes are typical mesenchymal markers associated with the EMT process, influencing carcinoma metastasis (Thiery, 2002; Shioiri et al, 2006). Our data showed that Vimentin and Slug could be downregulated in CXCR4 knockdown cells. It is consistent with the study on oral carcinomas which showed that CXCR4 could influence EMT formation and cancer invasion (Onoue et al, 2006).

Among the chemokine and chemokine receptors interaction, SDF-1 was proved to be a stimulator of invasion for CXCR4- 
positive cancer cells (Kollmar et al, 2007). To determine whether the effect of CXCR4 shRNA on metastasis was related to pancreatic cancer in vitro, we conducted the Matrigel chamber invasion assay. Our data showed under normal conditions, the invasive ability of CXCR4-transfected cancer cells was inhibited compared with the control cells. Moreover, much more difference was observed between control cells and CXCR4 knockdown cells after SDF-1 stimulation. However, we also found that as there was $70 \%$ inhibition of CXCR4 through shRNA, the invasive ability could not be totally blocked.

CXCR4 was a promising marker for pancreatic cancer progression. The CXCR4-positive expression was considered to be associated with a poor clinical outcome. Moreover, the abrogation of CXCR 4 could influence the pancreatic cancer cell phenotype including cell proliferation, colony formation, and cell invasion through the inhibition of canonical Wnt pathway. Given the important role that CXCR4 plays in the process of pancreatic cancer progression, CXCR4 is a very intriguing therapeutic target. Understanding the precise mechanisms of CXCR4 function should provide insight into attractive pancreatic cancer therapy.

\section{ACKNOWLEDGEMENTS}

We appreciate Professor Joshua B Rubin in Washington University School of Medicine at St Louis for kindly providing the phosphorylated CXCR4-specific antibody. We also appreciate the technical assistance of Dr Xinyang Wang, Dr Yuanyi You, and thank Professor Xu Li, Professor Wei Chen for helpful discussion and paper revision. This work was supported by grants from the National Natural Science Foundation of China (No. 30700817), the Natural Science Foundation of Shaanxi Scientific and Technical Bureau, China (No. 2006K09-G7), the Natural Science Foundation of Xi'an Scientific Bureau, China (No. GG06178).

\section{REFERENCES}

Abraham SC, Klimstra DS, Wilentz RE, Yeo CJ, Conlon K, Brennan M, Cameron JL, Wu TT, Hruban RH (2002) Solid-pseudopapillary tumors of the pancreas are genetically distinct from pancreatic ductal adenocarcinomas and almost always harbor beta-catenin mutations. Am J Patho 160: $1361-1369$

Al-Aynati MM, Radulovich N, Riddell RH, Tsao MS (2004) Epithelialcadherin and beta-catenin expression changes in pancreatic intraepithelial neoplasia. Clin Cancer Res 10: 1235-1240

Bachelder RE, Wendt MA, Mercurio AM (2002) Vascular endothelial growth factor promotes breast carcinoma invasion in an autocrine manner by regulating the chemokine receptor CXCR4. Cancer Res 62: $7203-7206$

Balkwill F (2004a) Cancer and the chemokine network. Nat Rev Cancer 4: $40-50$

Balkwill F (2004b) The significance of cancer cell expression of the chemokine receptor CXCR4. Semin Cancer Biol 14: 171-179

Billadeau DD, Chatterjee S, Bramati P, Sreekumar R, Shah V, Hedin K, Urrutia R (2006) Characterization of the CXCR4 signaling in pancreatic cancer cells. Int J Gastrointest Cancer 37: 110-119

Brabletz T, Jung A, Reu S, Porzner M, Hlubek F, Kunz-Schughart LA, Knuechel R, Kirchner T (2001) Variable beta-catenin expression in colorectal cancers indicates tumor progression driven by the tumor environment. Proc Natl Acad Sci USA 98: 10356-10361

Brand S, Dambacher J, Beigel F, Olszak T, Diebold J, Otte JM, Göke B, Eichhorst ST (2005) CXCR4 and CXCL12 are inversely expressed in colorectal cancer cells and modulate cancer cell migration, invasion and MMP-9 activation. Exp Cell Res 310: $117-130$

Burger JA, Kipps TJ (2006) CXCR4: a key receptor in the crosstalk between tumor cells and their microenvironment. Blood 107: 1761-1767

Butturini G, Stocken DD, Wente MN, Jeekel H, Klinkenbijl JH, Bakkevold KE, Takada T, Amano H, Dervenis C, Bassi C, Buchler MW, Neoptolemos JP (2008) Influence of resection margins and treatment on survival in patients with pancreatic cancer: meta-analysis of randomized controlled trials. Arch Surg 143: $75-83$

Hart CA, Brown M, Bagley S, Sharrard M, Clarke NW (2005) Invasive characteristics of human prostatic epithelial cells: understanding the metastatic process. Br J Cancer 92: 503-512

Helbig G, Christopherson KW, Bhat-Nakshatri P, Kumar S, Kishimoto H, Miller KD, Broxmeyer HE, Nakshatri H (2003) NF-kappaB promotes breast cancer cell migration and metastasis by inducing the expression of the chemokine receptor CXCR4. J Biol Chem 278: $21631-21638$

Ilyas M (2005) Wnt signalling and the mechanistic basis of tumour development. J Pathol 205: $130-144$

Jemal A, Siegel R, Ward E, Murray T, Xu J, Thun MJ (2007) Cancer statistics, 2007. CA Cancer J Clin 57: 43-66

Jiang YP, Wu XH, Shi B, Wu WX, Yin GR (2006) Expression of chemokine CXCL12 and its receptor CXCR4 in human epithelial ovarian cancer: an independent prognostic factor for tumor progression. Gynecol Oncol 103: $226-233$
Kajiyama H, Shibata K, Terauchi M, Ino K, Nawa A, Kikkawa F (2008) Involvement of SDF-1alpha/CXCR4 axis in the enhanced peritoneal metastasis of epithelial ovarian carcinoma. Int J Cancer 122: 91 -99

Kollmar O, Rupertus K, Scheuer C, Junker B, Tilton B, Schilling MK, Menger MD (2007) Stromal cell-derived factor-1 promotes cell migration and tumor growth of colorectal metastasis. Neoplasia 9: 862-870

Leo C, Horn LC, Rauscher C, Hentschel B, Liebmann A, Hildebrandt G, Hockel M (2006) Expression of erythropoietin and erythropoietin receptor in cervical cancer and relationship to survival, hypoxia, and apoptosis. Clin Cancer Res 12: 6894-6900

Liang Z, Yoon Y, Votaw J, Goodman MM, Williams L, Shim H (2005) Silencing of CXCR4 blocks breast cancer metastasis. Cancer Res 65: 967-971

Livak KJ, Schmittgen TD (2001) Analysis of relative gene expression data using real-time quantitative PCR and the 2(-Delta Delta C(T)) Method. Methods 25: $402-408$

Lowy AM, Fenoglio-Preiser C, Kim OJ, Kordich J, Gomez A, Knight J, James L, Groden J (2003) Dysregulation of beta-catenin expression correlates with tumor differentiation in pancreatic duct adenocarcinoma. Ann Surg Oncol 10: $284-290$

Matteucci E, Locati M, Desiderio MA (2005) Hepatocyte growth factor enhances CXCR4 expression favoring breast cancer cell invasiveness. Exp Cell Res 310: $176-185$

Miao J, Kusafuka T, Kuroda S, Yoneda A, Zhou Z, Okada A (2003) Mutation of beta-catenin and its protein accumulation in solid and cystic tumor of the pancreas associated with metastasis. Int J Mol Med 11: $461-464$

Muller A, Homey B, Soto H, Ge N, Catron D, Buchanan ME, McClanahan T, Murphy E, Yuan W, Wagner SN, Barrera JL, Mohar A, Verastegui E, Zlotnik A (2001) Involvement of chemokine receptors in breast cancer metastasis. Nature 410: 50-56

Murphy PM (2001) Chemokines and the molecular basis of cancer metastasis. $N$ Engl J Med 345: $833-835$

Nawroth R, van Zante A, Cervantes S, McManus M, Hebrok M, Rosen SD (2007) Extracellular sulfatases, elements of the Wnt signaling pathway, positively regulate growth and tumorigenicity of human pancreatic cancer cells. PLoS 2: e392

Nelson WJ, Nusse R (2004) Convergence of Wnt, beta-catenin, and cadherin pathways. Science 303: $1483-1487$

Neth P, Ries C, Karow M, Egea V, Ilmer M, Jochum M (2007) The Wnt signal transduction pathway in stem cells and cancer cells: influence on cellular invasion. Stem Cell Rev 3: 18-29

O'Hayre M, Salanga CL, Handel TM, Allen SJ (2008) Chemokines and cancer: migration, intracellular signalling and intercellular communication in the microenvironment. Biochem J 409: 635-649

Onoue T, Uchida D, Begum NM, Tomizuka Y, Yoshida H, Sato M (2006) Epithelial-mesenchymal transition induced by the stromal cell-derived factor-1/CXCR4 system in oral squamous cell carcinoma cells. Int J Oncol 29: $1133-1138$

Ottaiano A, di Palma A, Napolitano M, Pisano C, Pignata S, Tatangelo F, Botti G, Acquaviva AM, Castello G, Ascierto PA, Iaffaioli RV, Scala S 
(2005) Inhibitory effects of anti-CXCR4 antibodies on human colon cancer cells. Cancer Immunol Immunother 54: 781-791

Pasca di Magliano M, Biankin AV, Heiser PW, Cano DA, Gutierrez PJ, Deramaudt T, Segara D, Dawson AC, Kench JG, Henshall SM, Sutherland RL, Dlugosz A, Rustgi AK, Hebrok M (2007) Common activation of canonical wnt signaling in pancreatic adenocarcinoma. PLoS ONE 2: e1155

Peifer M, Polakis P (2000) Wnt signaling in oncogenesis and embryogenesis-a look outside the nucleus. Science 287: 1606-1609

Reya T, Clevers H (2005) Wnt signalling in stem cells and cancer. Nature 434: $843-850$

Rogers CD, Fukushima N, Sato N, Shi C, Prasad N, Hustinx SR, Matsubayashi H, Canto M, Eshleman JR, Hruban RH, Goggins $M$ (2006) Differentiating pancreatic lesions by microarray and QPCR analysis of pancreatic juice RNAs. Cancer Biol Ther 5: 1383-1389

Saur D, Seidler B, Schneider G, Algül H, Beck R, Senekowitsch-Schmidtke $\mathrm{R}$, Schwaiger M, Schmid RM (2005) CXCR4 expression increases liver and lung metastasis in a mouse model of pancreatic cancer. Gastroenterology 129: $1237-1250$

Schimanski CC, Bahre R, Gockel I, Müller A, Frerichs K, Hörner V, Teufel A, Simiantonaki N, Biesterfeld S, Wehler T, Schuler M, Achenbach T, Junginger T, Galle PR, Moehler M (2006) Dissemination of hepatocellular carcinoma is mediated via chemokine receptor CXCR4. Br J Cancer 95: 210-217

Schrader AJ, Lechner O, Templin M, Dittmar KE, Machtens S, Mengel M, Probst-Kepper M, Franzke A, Wollensak T, Gatzlaff P, Atzpodien J, Buer J, Lauber J (2002) CXCR4/CXCL12 expression and signaling in kidney cancer. Br J Cancer 86: $1250-1256$

Shioiri M, Shida T, Koda K, Oda K, Seike K, Nishimura M, Takano S, Miyazaki $M$ (2006) Slug expression is an independent prognostic parameter for poor survival in colorectal carcinoma patients. Br J Cancer 94: 1816-1822

Singh S, Sadanandam A, Singh RK (2007) Chemokines in tumor angiogenesis and metastasis. Cancer Metastasis Rev 26: 453-467
Staller P, Sulitkova J, Lisztwan J, Moch H, Oakeley EJ, Krek W (2003) Chemokine receptor CXCR4 downregulated by von Hippel-Lindau tumour suppressor pVHL. Nature 425: 307-311

Taketo MM (2006) Wnt signaling and gastrointestinal tumorigenesis in mouse models. Oncogene 25: 7522-7530

Thiery JP (2002) Epithelial-mesenchymal transitions in tumour progression. Nat Rev Cancer 2: $442-454$

Wang Z, Ma Q (2007) Beta-catenin is a promising key factor in the SDF-1/CXCR4 axis on metastasis of pancreatic cancer. Med Hypotheses 69: $816-820$

Wehler T, Wolfert F, Schimanski CC, Gockel I, Herr W, Biesterfeld S, Seifert JK, Adwan $\mathrm{H}$, Berger $\mathrm{MR}$, Junginger $\mathrm{T}$, Galle $\mathrm{PR}$, Moehler M (2006) Strong expression of chemokine receptor CXCR4 by pancreatic cancer correlates with advanced disease. Oncol Rep 16: $1159-1164$

Winter JM, Cameron JL, Campbell KA, Arnold MA, Chang DC, Coleman J, Hodgin MB, Sauter PK, Hruban RH, Riall TS, Schulick RD, Choti MA, Lillemoe KD, Yeo CJ (2006) 1423 pancreaticoduodenectomies for pancreatic cancer: a single-institution experience. J Gastrointest Surg 10: $1199-1210$

Woerner BM, Warrington NM, Kung AL, Perry A, Rubin JB (2005) Widespread CXCR4 activation in astrocytomas revealed by phosphoCXCR4-specific antibodies. Cancer Res 65: $11392-11399$

Yoshitake N, Fukui H, Yamagishi H, Sekikawa A, Fujii S, Tomita S, Ichikawa K, Imura J, Hiraishi H, Fujimori T (2008) Expression of SDF-1 alpha and nuclear CXCR4 predicts lymph node metastasis in colorectal cancer. Br J Cancer 98: 1682-1689

Zeng G, Germinaro M, Micsenyi A, Monga NK, Bell A, Sood A, Malhotra V, Sood N, Midda V, Monga DK, Kokkinakis DM, Monga SP (2006) Aberrant Wnt/beta-catenin signaling in pancreatic adenocarcinoma. Neoplasia 8: 279-289 